\title{
Expansion of the Distance Modality in Brazilian Higher Education: Implications for Quality and Equity
}

\author{
Julio Bertolin ${ }^{1}$ D $\cdot$ Tristan McCowan ${ }^{2} \cdot$ Helio Radke Bittencourt ${ }^{3}$
}

(c) International Association of Universities 2021

\begin{abstract}
With globalization and the knowledge society, the expansion of higher education has become an 'object of desire' among governments to bolster both economic growth and social development. In recent decades, just as in other countries, Brazil has expanded the system and become the fourth largest in the world in enrollment numbers, significantly increasing distance education at for-profit private institutions. However, massification without the necessary attention to quality and equity may present undesired consequences. Thus, considering Brazil has created one of the largest information databases that allow for studies with huge samples, we statistically analyzed performance in a wide scale national examination (Enade) with approximately 222,000 students, disaggregated by background and education modalities. The results back the argument that learning possibilities and performance in distance education are inferior in relation to in-person modalities and that the expansion based on distance education at for-profit private institutions may be reproducing inequalities within the higher education system in one of the most unequal nations in the world.
\end{abstract}

Keywords Brazilian higher education · Distance education · Equality · Massification · Quality

Julio Bertolin

julio@upf.br

Tristan McCowan

t.mccowan@ucl.ac.uk

Helio Radke Bittencourt

heliorb@pucrs.br

1 University of Passo Fundo, BR 285, São José district, Passo Fundo, RS 99052-900, Brazil

2 Institute of Education, University College London, 20 Bedford Way, London WC1H OAL, UK

3 PUC University, Ipiranga Avenue, 6681, Partenon, Porto Alegre, RS 90619-900, Brazil 


\section{Introduction}

With the emergence of globalization and the knowledge society, higher education has become even more important in terms of increasing private gains, enhancing efficiency and productivity, transferring technology, generating innovation and consolidating political institutions. The role of higher education in sustaining economic and social development has made its diversification and expansion an imperative in most countries (Altbach et al. 2017), which have sought to transition from a system for the elite to a system for the masses or universal access (Trow 1973). Consequently, a rise in enrollment rates has become central to education policies, generating estimates that the current 250 million enrollments in undergraduate programs around the world will rise to 380 million by 2030 (Calderon 2018).

The mere increase in enrollments and the issue of diplomas, however, do not guarantee an effective or socially just system. Despite ample recognition of the importance of earning a diploma, literature over the past twenty years has shown that the level of education only partially explains the impact of education on social and economic inequality (Gerber and Cheung 2008; Boliver 2011; Triventi 2013; Denice 2015). Significant differences in income and professional status are noted among people with higher education, indicating that this distinction does not ensure equal opportunities for undergraduates. A highly diversified system, based on groups of hierarchically classified institutions, may be responsible for generating significantly different levels of opportunities.

Within countries in the Global South, the expansion of higher education has also been rapid. In the first decade of this century, the rise in the number of students in Brazil, China and India, for example, was three times higher than the world average (Morche 2012). Some of these nations, despite being economically robust, lack education systems that provide more opportunities and social mobility. For example, even though Brazil has one of the world's largest economies (in 2017, the Brazilian GDP surpassed Russia, Canada, Australia and Spain), it has inequality indicators like the ninth worst Gini coefficient (World Bank 2020) and the second highest income concentration in the world-the wealthiest $1 \%$ holds almost $1 / 3$ of the national income (WID 2015).

Faced with the challenge of expanding the population's level of education, over the past three decades, Brazil has increased enrollments in higher education from some 1.5 million to more than 8.5 million. In terms of the net enrollment ratio (NER), though still low when comparing with OECD countries, there was an increase from 7\% at the start of the century to 20\% in 2017 (INEP 2019). Currently, the country is home to the fourth largest system in the world-behind only China, India and the USA (UNESCO 2020). It is a highly differentiated system: within the public sector, there are federal and state institutions (in addition to a small number of municipal ones), with technical, as well as academically focused institutions. In the private sector, there are for-profit and non-profit institutions, the latter consisting of religious, philanthropic and community institutions (Schwartzman et al. 2021). Quality and prestige vary across these diverse institutional types. However, as a general rule, free-of-charge public universities 
are higher in the rankings, more competitive in terms of admissions and publish more than their private counterparts (Cross et al. 2017), are free of charge and have highly competitive selection processes. Private institutions, on the other hand, are for the most part teaching-only institutions and have more vacancies than applicants.

The great Brazilian expansion has for the most part been located in the private sector, which has increased its proportion of enrollments from $58 \%$ in 1995 to $75 \%$ in 2018 (INEP 2019). In recent years, the for-profit institutions which make up a significant part of the private sector have adopted distance education as a growth strategy. While in 2005 , fewer than $2 \%$ of the non-state institution enrollments were for distance programs, in 2018, this modality represented almost $30 \%$. The volume of vacancies offered through this modality surpassed those of in-person courses for the first time in 2018-7.2 million compared to 6.4 million (INEP 2019).

This expansion strategy based on a combination of private institutions and distance education has generated concern within the academic community (TPE 2019). In addition to this modality making the learning process more complex on account of new configurations of time and space, the distance programs have attracted students with more challenging backgrounds than those of in-person students. Thus, many of the students from a lower social and economic level may be obtaining information of a poorer quality from some extremely basic institution and as such have reduced their opportunities for future gains and social mobility (McCowan and Bertolin 2020).

Distance education has been an important part of the rapid expansion of higher education globally in recent years. While correspondence courses have had a long existence, the founding of the Open University in the UK, and similar institutions in other countries (such as the University of South Africa), had a significant democratizing role on access, allowing possibilities of study for full-time workers, those with caring and domestic responsibilities, and those in remote geographical locations. The growth of the Internet gave an obvious spur to these distance programs and led to a major expansion, including the emergence of what are by far the largest institutions in the world: the Indira Gandhi National Open University in India and the Allama Iqbal Open University in Pakistan, with students numbering in the millions. The value of alternatives to in-person provision has become particularly clear in the context of COVID-19 (Marinoni et al. 2020; Salmi 2020). However, the pandemic has also shown that providing high quality distance education is not straightforward, and the effectiveness of the instruction varies markedly. Low quality distance higher education may provide an opportunity to expand access at low cost, but will provide little benefit to those students newly accessing the system.

This article aims to verify these complex questions for a large sample of Brazilian undergraduate students. It assesses the learning outcomes for students on distance and in-person modalities, and the ways these outcomes are linked to various aspects of socioeconomic background-mother's education, public/private schooling and family income-for different courses. In doing so, it provides insights into the extent to which distance education in Brazil serves to expand opportunities in an equitable manner, or alternatively entrench existing socioeconomic inequalities more deeply. The analysis draws on the notion of horizontality (McCowan 2016), to interrogate 
the level of stratification of opportunities in Brazilian higher education, leading to implications for policy for the future development of the system.

The study utilizes a quantitative research design, providing a statistical comparison of student performance on standardized assessments. For this end, one of the world's largest higher education student databases (Enade) was used. The database contains information on social and economic profiles and the performance of undergraduate students in examinations, highlighting the complex relations between the private expansion of distance education and issues related to quality and equity in higher education. Further information on the dataset and the statistical methods employed is provided in the sections that follow.

Two clarifications are needed on the scope of this article. First, the study does not intend to make a general critique of the impact and potential of distance education globally: it is acknowledged that in many cases, online courses have expanded opportunities to groups that would not have access to conventional higher education, and if well-designed can provide a stimulating learning environment. The assessment made here is specifically about the impact of distance education within the for-profit higher education sector in Brazil. Second, this study does not look specifically at the shifts to distance education that occurred in the context of the COVID19 pandemic: these shifts are distinct, in that students were rapidly and temporarily transferred to distance mode from face-to-face courses, when the latter mode became impossible. In contrast, the study focuses on distance education as a permanent option, in a context in which students make the choice between face-to-face and distance modes.

\section{Relating quality and equity}

An analysis of the relevance of higher education for societal development, going beyond descriptive studies of quantitative indicators (enrollments, graduating students, etc.), calls for close attention to the qualitative aspects of the system. When arguing in favor of the existence of a basic right to higher education, McCowan highlighted the inadequacy of expanded access without quality:

The question of the right to education inevitably involves quality, since we can only consider the right to have been realized if quality is of an acceptable level. There is little gain in ensuring access for 100 per cent of the population to universities with inadequate provision for learning (McCowan 2012, p. 122).

According to Schendel and McCowan (2015), the mistake of increasing the number of enrollments without the necessary attention to quality occurred in the past in processes to expand basic education in lower- income countries and that, as such, in the scope of higher education, it is necessary to pay attention to quality and learning, aimed at ensuring that academic organizations contribute more than merely 'issuing diplomas.' Quality of higher education is of course an intensely complex notion, and there are a range of legitimate conceptualizations (Cheng and Tam 1997; Harvey and Green 1993; Tam 2001). This article focuses specifically on quality gauged through student learning, rather than other functions of the university, such 
as research excellence. While broader, transformative, notions of learning in higher education are also crucial, it will not be possible to address these in this article; instead the focus will be solely on cognitive, academic learning outcomes for which comparable large-scale data are available.

The quantitative expansion of enrollments may, in itself, be a factor that jeopardizes the level of quality, generating undesired results through the learning provided. The recent experience of certain nations has shown the presence of the famed 'quality x quantity' pendulum in higher education, due to the rapid expansion of the systems having generated substantial problems in terms of qualitative loss (Altbach et al. 2009; European Commission 2010). Greater access without quality assurance oversight and regulation reduces the positive externalities for the social and economic environment that the rise in education level generates. Furthermore, poor quality education may be harmful when someone obtains a diploma without garnering the respective expertise and competences necessary to deal with certain situations that involve risk to human life.

The expansion of higher education also has the potential to impact aspects of system equity [1]. The ideal scenario would be for all academic institutions to provide equal opportunities for learning and future gains. An expansion process with no suitable control over the accreditation of new institutions, however, may lead to important differences in learning and performance among students. Consequently, students who graduate from elite or research-intensive universities tend to obtain more knowledge, develop better competencies and attain academic performances that are superior in comparison with graduates from teaching-only institutions that do not conduct research. As the literature shows, some have greater possibilities for learning, for better examination performance (Bruinsma 2003; Bertolin et al. 2019) and for future gains and employability (Gerber and Cheung 2008).

Another aspect that jeopardizes the equity of a system is associated with the fact that higher education is a positional asset (Marginson 2004). Due to it being not the 'effective quality,' but rather the academic recognition that an institution enjoys within society that determines the value of a diploma obtained by its students, the institution and the courses attended (over which quite often, poorer students have little choice) may reduce future professional opportunities. According to Brighouse (2009, pg. 6), the credential of a diploma provides "greater competitiveness for desirable positions distributed unequally and the unequally distributed assets that are linked to them." To this end, Cyrulnik (2020) states that "nowadays, society selected by means of school and diploma: it is the new aristocracy. It is no longer the aristocracy of physical force or that of goods or factories [...]. The new aristocracy is that of the diploma". Consequentially, higher education expansion based on stratification, combining well-regarded research- intensive universities with new institutions lacking academic prestige, and which issue unaccredited diplomas, generates highly inequitable outcomes in terms of recognition and future gains.

The challenge of establishing a fair higher education system fostering equal opportunities is not at all simple. In theory, even if all the institutions were to offer quality education and possess academic prestige, not all would have the same opportunities for learning performance and future gains due to the diversity of student profiles. In the second half of the last century, Coleman et al. (1966) used a wide 
scale survey to show the variable that most strongly conditioned the performance of young students was the family, social, economic and cultural context. During the same period, Bourdieu (1966) criticized the theory that the school is a factor of social mobility, arguing that there is a system of family values handed down that is implicit and deeply internalized and which contributes to defining attitudes relative to an institute of learning and that, as a result, is responsible for rates of success and failure.

In subsequent years, studies related to higher education showed that the same was true for students, that is, those originating from families of lower social, economic and cultural status tend to obtain academic performances inferior to their colleagues from more privileged families, with a better background (Betts and Morell 1999; Bertolin and Marcon 2015). Works published on the performance of Brazilian university students sitting for the National Student Performance Examination (Enade [2]) have also highlighted the influence of social and economic level on performance. For example, Table 1 shows that the better the mother's education, the higher the grades of the 'Specific Component' for the Enade, which covers content from each degree course.

Thus, it becomes plausible to postulate that widening access to higher education, in itself, does not ensure the democratization and establishment of a fair system and may even generate inequality as the diversities resulting from expansion in terms of quality levels, institutional positional asset and even the background of the students influence the selectiveness and substantial opportunities within and outside the academic environment. To this end, studies resulting from growing massification of systems and their consequences for different social groups lead to the development of theories and proposals on criteria for the establishment of fairer higher education.

McCowan (2016), for example, argued that after considering aspects like availability (existence of places in higher education institutions) and accessibility (real opportunities for students to occupy those places), a system must display 'horizontality.' To the author, a system can be characterized as horizontal when its institutional difference is disciplinary area, ethos or mission, and not relative to quality or positional assets. In other words, horizontality exists when institutions and courses

Table 1 Student improvement by mother's education. Source: Bertolin et al. (2019)

\begin{tabular}{|c|c|c|c|c|c|c|}
\hline \multirow[t]{2}{*}{ Mother's education } & \multicolumn{3}{|c|}{ Private institutions } & \multicolumn{3}{|l|}{ IFES } \\
\hline & New students & $\begin{array}{l}\text { Students at } \\
\text { graduation }\end{array}$ & $\begin{array}{l}\text { Improve- } \\
\text { ment } \%\end{array}$ & New students & $\begin{array}{l}\text { Students at } \\
\text { graduation }\end{array}$ & $\begin{array}{l}\text { Improve- } \\
\text { ment } \%\end{array}$ \\
\hline None & 31.24 & 36.27 & 16 & 33.07 & 40.12 & 21 \\
\hline Up to $4^{\circ}$ & 32.98 & 40.61 & 23 & 35.29 & 45.53 & 29 \\
\hline Up to $8^{\circ}$ & 32.45 & 42.69 & 32 & 36.56 & 46.57 & 27 \\
\hline Upper secondary & 32.02 & 44.05 & 38 & 35.24 & 48.72 & 38 \\
\hline Higher & 31.91 & 46.17 & 45 & 35.75 & 53.14 & 49 \\
\hline
\end{tabular}

Specific Component, 2007 Edition of Enade

IFES federal higher education institutions 
present similar academic and social quality and status, fostering equal opportunities and equity in the learning process and outcomes obtained in income and professional fulfillment. This frame will be utilized in analyzing institutional differentiation in Brazilian higher education. Considering the objective of developing greater equity in higher education, it becomes pertinent to analyze the systems in contexts of increasing enrollments, especially where the new entrants are based on hierarchical institutions or in a modality that sustain questions about quality.

\section{The Question of Quality in the Distance Education Modality}

The expansion of distance education programs in higher education is a global phenomenon that has led to changes in many systems. Diverse countries have presented significant rises in enrollments in this modality (Department of Education 2010; Ziguras 2018; Bolton et al. 2019) that, despite not being new, has gained ground since the turn of the last century with the Internet and new online information and communication technologies. Advances in technology and new pedagogical approaches — such as the conversational framework of Laurillard (2013) - have ensured that distance education involves not only communication and absorption of content, but diverse forms of teacher-student and peer-to-peer interaction and coconstruction. The development of Massive Open Online Courses (MOOCs) since 2012, while not bringing the revolution imagined by some, has expanded the range of provision available even to those not formally enrolled in higher education institutions, including Global South contexts (Laurillard and Kennedy 2017).

Nevertheless, the expansion of distance education has also generated insecurity and provoked questions about its impact on the quality of systems. Doubts about the quality of distance education have become so significant that countries have begun to establish regulatory limits. Governments like those of China, India and Vietnam refuse to admit diplomas obtained through foreign distance education programs, arguing that the modality is of an inferior quality (Ziguras 2018). In Peru and Mexico, initial teacher education was prohibited if in the guise of distance programs (TPE 2019). In Brazil, professional bodies have approved resolutions that prevent distance education graduates from exercising certain professions. Entities representing architecture, pharmacy, veterinary medicine and dentistry argue that practical activities are essential and that, as such, it is not possible to guarantee a quality education without in-person classes. In October 2019, the Federal Prosecution Office submitted a recommendation to the Ministry of Education for the suspension of authorization to create new distance education course in the area of Health (Pinho 2019).

Manuel Castells, current minister of Universities in Spain and a globally renowned author, stated before Congress that "there is a poor image surrounding these [distance] education programs because some of the universities created are a pure farce" and that, as such, it is necessary to exercise "greater control over institutions with higher profits than education levels" (Silió 2019). Within this context of uncertainty, governments, international bodies and researchers have developed studies to assess the level of learning provided by graduate distance education programs 
and presented proposals to guarantee quality. Nevertheless, doubts and uncertainty remain. Questions about the effectiveness and the real possibilities of distance education still lack more consistent responses.

Distance education in Brazil has been located primarily in the private sector. The Open University of Brazil was established in 2005 as a collaboration between existing public universities and had an important role in expanding access, for example in the Amazon region (Alves 2017), yet growth there has stagnated and the vast majority of new enrollments are in the commercial private institutions. The expansion of access to distance education is significantly characterized by a student profile that, generally, presents a lower social and economic level and inferior study conditions than those enrolled in in-person learning modalities. On average, students in distance education programs have mothers with lower education levels, their families have lower income, they less frequently attend the better private schools during basic education and work more than in-person students (see Table 2).

Furthermore, distance education students generally take courses with a lower professional status in the perception of society (e.g., teacher education degrees and technological courses) and pay the lowest monthly fees among private institutionsthe average bachelor's degree distance course is almost $1 / 3$ of the cost of

the in-person program (ABMES 2019). The predominance of enrollments in this undergraduate course profile is largely due to the fact that the existing offer of this modality in private institutions is restricted to specific courses. In part, this restriction is due to the political influence of professional bodies, especially those relating to law, engineering and medicine, which have lobbied against the creation of new distance education courses in their disciplinary areas, especially in private institutions. There are some exceptions observed in public institutions that are provided by state governments, as for example in the Virtual University of the State of São Paulo (UNIVESP), which offers computing science and engineering.

Some comparative studies among distance education and in-person modalities in Brazilian higher education have been developed in recent years, though without consensus in the results presented. Figueiredo et al. (2017) postulate that examinations taken by graduate students in the distance education modality are mostly assessed as better or equal to the graduate students from the same courses offered in the in-person modality. Bielschowsky (2018) argues oppositely that in-person programs from the five private institutions that account for $58 \%$ of distance education enrollments in Brazil generally present results better than those obtained in their distance programs, suggesting that, in the best hypothesis, the treatment between the two modalities

Table 2 Characteristics of students in distance and in-person modalities in Brazilian higher education. Source: Authors, based on ABMES (2019)

\begin{tabular}{lll}
\hline Indicator & $\begin{array}{l}\text { Distance educa- } \\
\text { tion (\%) }\end{array}$ & In-person (\%) \\
\hline Mothers with higher education & 10 & 25 \\
Private upper secondary & 19 & 35 \\
Do not work & 16 & 39 \\
Families with higher income & 25 & 37 \\
\hline
\end{tabular}


would not be the same. However, these comparative studies have methodological limitations, especially because they do not consider the backgrounds of the students.

A rare exception is a comparison by the organization Todos pela Educação, entitled Initial Teacher Education in Brazil, published in August 2019. It used a methodology that controls for the effect of the student profile and estimated that the difference between the modalities in a way that indicates that distance learning graduates are more likely to do poorly in the Enade examination-30.2\% against $21.6 \%$ for in-person learning (TPE 2019). However, the scope of this work was limited to teacher education programs. Thus, comparative studies between the modalities that break down performance according to students' background and cultural capital, in a wider study of the system, are certainly necessary.

Such a comparison, considering the relation between quality and equity, will allow an investigation into the expansion of access in Brazil, based chiefly on the distance education modality at private for-profit institutions, to explore whether it is (or is not) producing and/or reproducing privileges within the higher education system.

\section{Performance Comparison Between Modalities}

In Brazil, the best source of information for the comparison of learning and performance among students from different contexts (e.g., types of institutions or education modality) in higher education is the Enade examination. It is one of the largest higher education databases in the world, with information on the examination applied on a wide scale, assessing student knowledge as pertaining to undergraduate courses through the application of a test split into two components: (1) Specific Component, which covers content from each degree course and (2) general education, which covers general knowledge. The questions from the general education component, which are the same for all courses, represent $25 \%$ of a student's final grade, while the Specific Component questions represent $75 \%$.

However, only the Specific Component grade seems suitable for a performance comparison among different groups of students. This is due to the fact that the general education grade is significantly influenced by the cultural capital (background) of the student, which is also acquired and developed in non-academic spaces, especially within the family. Consequentially, as the Specific Component questions are exclusive to each course studied, the comparison can only be made within the series of courses with the same education.

Besides the examination questions, Enade also has questionnaires, one for the students and another for the course coordinators. The students' questionnaire has diverse questions regarding the social, economic and cultural conditions of each participant, their families and their social origin. This information is vital in assessing quality, as it allows the performance of large groups of students to be broken down into different levels of background. Notwithstanding the alternation of courses with each edition (Enade uses three-year cycles, in other words, the programs from one disciplinary area take part once every three years), in some cases, the participation reaches almost 500.000 students. The Enade data set constitutes a 
representative sample of the total number 8.6 million students enrolled in Brazilian higher education.

Studies have pointed to problems arising from the use of ENADE to assess student learning and performance (OECD 2018). In this article, to overcome such limitations, longitudinal comparisons were not made, not even between courses of different careers, and the CPC indicators and the ENADE concept (grades) were not used. Since 2011, the ENADE is not applied to freshman students, which makes it impossible to measure the initial performance, as well as the added value during the course through ENADE examination. Thus, the recent editions of ENADE used in the developed study (2015, 2016 and 2017) did not have the participation of incoming students. However, as shown in Table 1 of the article, it can be observed that the students' grades in the Specific Component of each career (which is the comparison criterion adopted by the study), when ENADE still had the participation of incoming students, did not vary significantly between groups from different backgrounds in the group of private institutions (used in the study), which does not indicate the possibility of a significant bias due to the eventual selectivity of on-site courses.

Thus, with the aim of comparing learning and performance between distance education and in- person modalities, within a three-year Enade cycle (2015/2016/2017), all the participants (graduating students) from the courses in question were selected exclusively from private institutions, with a higher number of distance education participants in each of the three editions. The private sector was selected for the analysis - rather than public institutions (either federal, state or municipal) —as this is where the majority of distance students are located (allowing for a better comparison between distance and in-person education), and where the hypothesized exacerbation of inequalities exists. In all, considering both education models, the number of students selected for each course was business administration courses, in 2015 , with almost 109,000; social work courses, in 2016, with over 24,000; and teacher education courses, in 2017, with approximately 90,000. The final result was 222,542 students, with 132,924 in-person students and 89,618 distance education students. Their grades were considered in the comparisons made between in-person and distance education modalities (Calculations were based on tables available through http://portal.inep.gov.br/microdados and the IBM SPSS Statistics software, version 20.0).

In this wide sample, an initial comparison, disaggregated by education modality, showed that the proportion of in-person course students in the group who obtained the highest grades in the Specific Component is significantly higher than those in the distance learning modality, in the programs for the three courses analyzed (see Table 3).

If the likelihood of a student being part of the group with the highest grades was independent of the modality, a $25 \%$ rate would be expected in both in-person and distance education. However, the general results show that the percentages depend on the modality. While almost $30 \%$ of the business administration graduates in the in-person modality are among those with the highest grades, fewer than $15 \%$ of the students from this course who learn through distance education fall into this highlighted group. In the case of social work, the proportion of inperson students that fall within the group with the highest grades is still higher in 
Table 3 Student performance in distance and in-person modalities. Source: Authors, based on Inep (2019)

\begin{tabular}{|c|c|c|c|c|c|}
\hline & & \multicolumn{2}{|c|}{ Scores in bottom $75 \%$} & \multicolumn{2}{|c|}{ Scores in top $25 \%$} \\
\hline & & Number & Percent & Number & Percent \\
\hline \multirow[t]{2}{*}{ Business administration } & Distance education & 20038 & $85.7 \% *$ & 3352 & $14.3 \% *$ \\
\hline & In-person & 61346 & $71.7 \% *$ & 24159 & $28.3 \% *$ \\
\hline \multirow[t]{2}{*}{ Social Work } & Distance education & 10951 & $85.0 \% *$ & 1930 & $15.0 \% *$ \\
\hline & In-person & 7014 & $62.9 \% *$ & 4137 & $37.1 \% *$ \\
\hline \multirow[t]{2}{*}{ Teacher education } & Distance education & 41937 & $78.6 \% *$ & 11410 & $21.4 \% *$ \\
\hline & In-person & 25265 & $69.7 \% *$ & 11003 & $30.3 \% *$ \\
\hline
\end{tabular}

*Specific Component, Enade Cycle 2015/2016/2017

relation to those from the distance learning modality: $37.1 \%$ X $15.0 \%$. Similarly, in teacher education courses, the $30.3 \%$ of in-person graduates proportionally surpass the $21.4 \%$ of distance education students in the group comprised of those with the best performances. However, despite indicating a qualitative difference in favor of the in-person modality, the numbers from Enade do not consider the issue of background among participants.

Due to the importance of the influence of background on learning at all levels of education, comparing the performance between students from specific groups that consider this factor offers more accuracy. Thus, to follow is a presentation of the average grades in the Specific Component obtained by students in the Enade examination, split by learning modality and divided into subgroups considering the highest and lowest levels of background in the social indicators: total family income, mother's education and school type attended for upper secondary [3]. These calculations show that the performance of graduate students in the in-person modality was significantly higher [4] than those graduating through distance education, in the three courses analyzed, regardless of the students' social and economic levels (see Table 4).

In the business administration and social work courses, in the six comparisons made, both in the three subgroups with a higher background and in the three subgroups with the lower background, the results showed averages significantly higher for in-person students. In the case of social work, in some comparisons, the difference in averages among subgroups was as high as ten points.

The performance difference between modalities did not present statistical significance in only one comparison for the teacher education course. This was for the subgroup of students that attended a private upper secondary school, considered to have higher socioeconomic level. However, even so, in terms of absolute value, the distance education performance was lower. Thus, these averages are evidence that even when considering the differences in background among students, the comparisons are hugely favorable toward the in-person modality in terms of providing better learning conditions and performance. 
Table 4 Student performance in distance and in-person modalities, by socioeconomic background. Source: Authors, based on Inep (2019)

\begin{tabular}{|c|c|c|c|c|c|c|c|c|}
\hline \multirow[t]{2}{*}{ Indicator } & & \multirow[t]{2}{*}{ Modality } & \multicolumn{2}{|c|}{$\begin{array}{l}\text { Business adminis- } \\
\text { tration }\end{array}$} & \multicolumn{2}{|c|}{ Social work } & \multicolumn{2}{|c|}{ Teacher education } \\
\hline & & & Number & Average & Number & Average & Number & Average \\
\hline \multirow[t]{4}{*}{ Family income } & $\begin{array}{l}\text { Higher } \\
\text { income }\end{array}$ & In-person & 34627 & 40.3 & 1312 & 50.9 & 3361 & 47.1 \\
\hline & & Distance & 7610 & 35.6 & 1714 & 42.4 & 7417 & 46.3 \\
\hline & Lower income & In-person & 31035 & 35.9 & 8292 & 47.1 & 26421 & 41.3 \\
\hline & & Distance & 10271 & 31.2 & 9039 & 36.6 & 34038 & 35.7 \\
\hline \multirow[t]{4}{*}{$\begin{array}{l}\text { Mother's } \\
\text { Education }\end{array}$} & $\begin{array}{l}\text { Higher educa- } \\
\text { tion }\end{array}$ & In-person & 15057 & 41.2 & 994 & 49.5 & 3040 & 44.7 \\
\hline & & Distance & 2562 & 34.7 & 873 & 38.2 & 4539 & 41.4 \\
\hline & None & In-person & 2889 & 35.1 & 1159 & 44.8 & 3515 & 38.9 \\
\hline & & Distance & 1632 & 31.3 & 1815 & 36.6 & 6324 & 35.2 \\
\hline \multirow{4}{*}{$\begin{array}{l}\text { Upper second- } \\
\text { ary }\end{array}$} & Private & In-person & 17590 & 41.5 & 1071 & 50.8 & 2496 & 46.5 \\
\hline & & Distance & 2214 & 36.8 & 796 & 40.6 & 3527 & 46.0 \\
\hline & Public & In-person & 59193 & 37.3 & 8935 & 47.9 & 31417 & 42.3 \\
\hline & & Distance & 18422 & 32.5 & 10717 & 37.8 & 45246 & 37.6 \\
\hline
\end{tabular}

Higher income $=4.5$ minimum wages or higher Lower income $=\mathrm{Up}$ to 3 minimum wages

Higher Education $=$ With an undergraduate and/or graduate degree. None $=$ Primary education incomplete

Private $=$ Attended a private upper secondary school. Public $=$ Attended a public upper secondary school *Specific Component, Enade Cycle 2015/2016/2017

In order to attain a more complete assessment of the effect of the background on the performance in the test, together with the effect of the modality, a multiple logistic regression was also conducted, whereby the dependent variable was placed in the group with $25 \%$ highest grades. This technique provides a simultaneous estimate of the impacts of the education modality and the background, allowing for better understanding of the effect of education (provided by the course) on the grades obtained by students.

Twelve control variables associated with the profile of students were selected to compose the series of predictor variables, such as sex, marital status, skin colour, age, family size, income, parents' education, welfare, affirmative policy, upper secondary education, state (province) and learning modality (see Table 5).

The results found for the odds ratio ratified that the modality is a relevant factor, revealing that in-person modality students have a greater odds ratio [5] of being classified in the group with the highest grades in the Specific Component of Enade for their course (see Table 6).

The chance of in-person students being classified in the groups with the highest grades (among the top 25\%) in the Specific Component is significantly greater than those of the distance education modality: almost 60\% (odds ratio 
Table 5 Descriptive statistics for the logistic regression predictor variables by courses. Source: Authors, based on Inep (2019)

\begin{tabular}{|c|c|c|c|c|}
\hline \multirow[t]{3}{*}{ Variables } & \multirow[t]{3}{*}{ Categories } & \multirow{2}{*}{$\begin{array}{l}\begin{array}{l}\text { Business Adminis- } \\
\text { tration }\end{array} \\
(n=108,895)\end{array}$} & \multirow{2}{*}{$\begin{array}{l}\text { Social Work } \\
(n=24,032)\end{array}$} & \multirow{2}{*}{$\begin{array}{l}\text { Teacher Education } \\
(n=47678)\end{array}$} \\
\hline & & & & \\
\hline & & Percent Mean+ SD & Percent Mean+ SD & Percent Mean+ SD \\
\hline \multirow[t]{2}{*}{ Modality } & Distance & $21.5 \%$ & $53.6 \%$ & $76.1 \%$ \\
\hline & In-person & $78.5 \%$ & $46.4 \%$ & $23.9 \%$ \\
\hline \multirow[t]{2}{*}{ Female } & No & $41.3 \%$ & $7.7 \%$ & $5.4 \%$ \\
\hline & Yes & $58.7 \%$ & $92.3 \%$ & $94.6 \%$ \\
\hline \multirow[t]{2}{*}{ Unmarried } & No & $33.6 \%$ & $51.6 \%$ & $60.0 \%$ \\
\hline & Yes & $66.4 \%$ & $48.4 \%$ & $40.0 \%$ \\
\hline \multirow{2}{*}{$\begin{array}{l}\text { Skin colour: } \\
\text { white }\end{array}$} & No & $40.6 \%$ & $68.1 \%$ & $49.1 \%$ \\
\hline & Yes & $59.4 \%$ & $31.9 \%$ & $50.9 \%$ \\
\hline \multirow{6}{*}{$\begin{array}{l}\text { Parents' educa- } \\
\text { tion }\end{array}$} & None & $2.1 \%$ & $7.4 \%$ & $7.8 \%$ \\
\hline & Up to 5 th year & $22.1 \%$ & $37.9 \%$ & $41.6 \%$ \\
\hline & Up to 8 th year & $16.5 \%$ & $15.4 \%$ & $14.9 \%$ \\
\hline & $\begin{array}{l}\text { Upper second- } \\
\text { ary }\end{array}$ & $36.2 \%$ & $27.4 \%$ & $23.1 \%$ \\
\hline & Undergraduate & $16.2 \%$ & $9.0 \%$ & $9.0 \%$ \\
\hline & Graduate & $6.9 \%$ & $2.9 \%$ & $3.6 \%$ \\
\hline \multirow[t]{2}{*}{ Scholarship } & No & $54.6 \%$ & $55.3 \%$ & $65.6 \%$ \\
\hline & Yes & $45.4 \%$ & $44.7 \%$ & $34.4 \%$ \\
\hline \multirow{2}{*}{$\begin{array}{l}\text { Affirmative } \\
\text { policy }\end{array}$} & No & $79.6 \%$ & $75.8 \%$ & $82.6 \%$ \\
\hline & Yes & $20.4 \%$ & $24.2 \%$ & $17.4 \%$ \\
\hline \multicolumn{5}{|l|}{$\begin{array}{l}\text { Upper second- } \\
\text { ary }\end{array}$} \\
\hline & All in public & $71.6 \%$ & $82.2 \%$ & $85.8 \%$ \\
\hline & All in private & $18.3 \%$ & $7.8 \%$ & $6.6 \%$ \\
\hline & All overseas & $0.1 \%$ & $0.0 \%$ & $0.1 \%$ \\
\hline & Mostly public & $5.7 \%$ & $6.9 \%$ & $5.2 \%$ \\
\hline & Mostly private & $4.0 \%$ & $3.0 \%$ & $2.3 \%$ \\
\hline & Partially overseas & $0.4 \%$ & $0.0 \%$ & $0.1 \%$ \\
\hline \multicolumn{5}{|l|}{$\begin{array}{l}\text { Modality ofupper } \\
\text { secondary }\end{array}$} \\
\hline & Traditional & $83.5 \%$ & $69.7 \%$ & $60.1 \%$ \\
\hline & Technical & $8.6 \%$ & $8.7 \%$ & $5.9 \%$ \\
\hline & Teaching & $2.0 \%$ & $7.8 \%$ & $21.1 \%$ \\
\hline & Evening courses & $5.1 \%$ & $12.1 \%$ & $11.3 \%$ \\
\hline & Other & $0.8 \%$ & $1.7 \%$ & $1.5 \%$ \\
\hline \multirow{2}{*}{$\begin{array}{l}\text { State/Region of } \\
\text { country }\end{array}$} & North & $3.4 \%$ & $4.6 \%$ & $3.1 \%$ \\
\hline & Northeast & $12.1 \%$ & $22.6 \%$ & $7.9 \%$ \\
\hline
\end{tabular}


Table 5 (continued)

\begin{tabular}{|c|c|c|c|c|c|c|c|}
\hline \multirow[t]{3}{*}{ Variables } & \multirow[t]{3}{*}{ Categories } & \multirow{2}{*}{\multicolumn{2}{|c|}{$\begin{array}{l}\text { Business Adminis- } \\
\text { tration }\end{array}$}} & \multirow{2}{*}{\multicolumn{2}{|c|}{$\begin{array}{l}\text { Social Work } \\
(n=24,032)\end{array}$}} & \multicolumn{2}{|c|}{ Teacher Education } \\
\hline & & & & & & \multicolumn{2}{|c|}{$(n=47678)$} \\
\hline & & Percent & Mean+ SD & Percent & Mean+ SD & Percent & Mean+ SD \\
\hline & Southeast & $47.8 \%$ & & $27.4 \%$ & & $48.2 \%$ & \\
\hline & South & $27.8 \%$ & & $32.9 \%$ & & $28.1 \%$ & \\
\hline & Central West & $9.0 \%$ & & $12.5 \%$ & & $12.7 \%$ & \\
\hline Age (years) & & & $28.0+6.9$ & & $34.6+9.8$ & & $33.4+9.2$ \\
\hline Family size & & & $3.6+1.5$ & & $3.9+1.6$ & & $3.9+1.5$ \\
\hline $\begin{array}{l}\text { Household } \\
\text { Income (num- } \\
\text { ber of mini- } \\
\text { mum salaries) }\end{array}$ & & & $5.9+6.2$ & & $2.9+2.5$ & & $3.3+3.0$ \\
\hline
\end{tabular}

Table 6 Odds ratios for students in distance and in-person modalities Source: Authors, based on Inep (2019)

\begin{tabular}{|c|c|c|c|c|c|c|c|c|}
\hline \multirow[t]{2}{*}{ Program } & \multirow[t]{2}{*}{ Beta } & \multirow[t]{2}{*}{ S.E.(Beta) } & \multirow[t]{2}{*}{ Wald } & \multirow[t]{2}{*}{ df } & \multirow[t]{2}{*}{ p-value } & \multirow[t]{2}{*}{ Odds Ratio } & \multicolumn{2}{|c|}{ 95\% C.I.for OR } \\
\hline & & & & & & & Lower & Upper \\
\hline Teacher Education & 0.343 & 0.020 & 305.776 & 1 & 0.000 & 1.409 & 1.356 & 1.465 \\
\hline Social Work & 0.930 & 0.040 & 542.191 & 1 & 0.000 & 2.535 & 2.344 & 2.741 \\
\hline Business Administration & 0.460 & 0.023 & 405.751 & 1 & 0.000 & 1.584 & 1.515 & 1.657 \\
\hline
\end{tabular}

* Enade Cycle 2015/2016/2017.

1.584) higher for participants in business administration programs, over $150 \%$ (odds ratio 2.535) greater for social work students and 40\% (odds ratio 1.409) greater for teacher education students.

As such, these differences that emerge in the comparison between the grades obtained by students participating in Enade from different education modalities show that, regardless of the background, the likelihood of learning and better performance are significantly higher for those who attend in-person graduate programs. In light of this, when considering that the portion of students from a lower social, economic and cultural level is higher in the distance education modality, it is possible to deduce that Brazilian higher education is substantiated by an unfair system: those born into a more privileged background and higher cultural capital tend to enroll on the education modality with the best possibility of performance and those with an inferior background, potentially with a less favorable social origin, tend to enroll in the modality with inferior 'quality.' 


\section{Conclusion}

The extraordinary positional advantage conferred on those who have an undergraduate diploma is a contemporary phenomenon, as is true for the increase in other selectivity benefits and study differences at a higher level. Recent studies show that in most countries nowadays, the returns from higher education are superior to those provided by other levels of education (Herbaut and Geven 2019). This makes it important to ensure more poor students with a lower social and economic level are entering, especially within the context of societies with expressive inequality, like Brazil. Nevertheless, said access is no guarantee of establishing a fair system.

Groups of hierarchicalized institutions, lacking horizontality in terms of quality and academic status among different universities, schools and programs may generate significantly distinct levels of opportunities and gains among those with diplomas (McCowan 2016). Thus, higher education expansion processes that simply create places without regulating academic quality and values of the new institutions could bolster unfair systems, which produce and reproduce privileges for students from a higher social and economic level.

Even within a context of expansion, it is very difficult to justify-morally and even instrumentally - the establishment of a higher education system in which access to students from wealthy families is more common in elite institutions, with recognized quality and prestigious diplomas, while the entrance of students from a lower social, economic and cultural level is predominantly into institutions with little academic status, questionable quality and which issue diplomas with low value in the job market (McCowan and Bertolin 2020). Especially in developing nations like Brazil, with elevated social inequality, it is fundamental that higher education contributes to social mobility, in a way that fosters balanced opportunities for all, regardless of students' social origin.

The comparative analyses for this paper on the performance of over 222,000 Brazilian students in the national Enade examination show that learning opportunities and performance for in-person and distance modalities do not tend to be equal. After annulling or disaggregating the important effect of background, average grades for in-person students are significantly higher than the average grades of those studying through distance courses - in some cases exceeding 10 points - along with the likelihood of an in-person student being among those with the highest grades is much higher, between $40 \%$ and $150 \%$ more than a student studying through distance education. As the social and economic level of distance education students is generally lower, when relating this empirical evidence to the required horizontality for system to be fairer, it becomes plausible to infer that the expansion of Brazilian higher education is generating inequality.

It is important to point out that this article is not arguing against distance education per se. Distance modalities have played an important role in expanding educational access for those in remote geographical locations, or with particular life circumstances that prevent in-person attendance, and have come to the fore during the coronavirus pandemic. The negative impacts in the Brazilian case stem from combination of distance education with for-profit higher education, the latter aiming to 
drive down costs and maximize reach, with little regard for educational quality and public good implications. The market incentives for improvement of quality in these courses are weak, given the huge demand for higher education credentials, and government regulation of the private sector has been unable to ensure a high minimum level.

If the expansion process for access to Brazilian higher education continues to be sustained by the growth of distance education, it will soon be possible to apply the metaphor of segregating 'lifts'. The system will be like two social lifts, one that reaches the highest floors and the 'luxury penthouse,' used mainly by in-person modality students, who generally have better cultural capital, belong to middle and upper classes; and another lift that only reaches the first few floors, often visited by distance education students, originating from families with lower socio-economic backgrounds. The first lift is chiefly represented by the elite institutions, with in-person courses, leading to careers that generate a positional advantage. The second lift corresponds to the private, for-profit institutions, with distance courses, in careers with less social recognition.

To a significant degree, this trend is related to massification, that only 'almost' democratizes, as it reflects the inequality of Brazilian society within the higher education system: differences in the level of development and future opportunities due to social origins that produce and reproduce unacceptable injustices in one of the most unequal countries in the world.

\section{Notes}

1. The term equity is derived from the Latin aequitas, from aequus (equal, equitable) and was used in the past in the sense of being analogous to justice. Currently, there are different concepts of equity, many related to the idea of needing to adapt a rule to a specific case, in order to make it fairer. Within the scope of higher education and this article, equity is understood as being related to the idea of equal opportunities.

2. Exame Nacional de Desempenho dos Estudantes.

3. The selection of variables like total family income, mother's education and upper secondary type attended used as background indicators was based on the literature that indicates these aspects as important conditions in the social, economic and cultural level of students in Brazil (Bertolin et al. 2019).

4. T tests conducted on samples from the analyzed base for the purpose of checking for statistical significance between the differences in the student subgroup averages with similar background indicators, through from different education modalities, resulted in 17 of the 18 comparisons considered for a confidence interval of $95 \%$, at a $p$ value $<0.05$. That is to say, they rejected the null hypothesis of the tests in a way that shows the relevance of performance variation among students from the in-person and distance education modality.

5. In the logistics regressions conducted, the modality coefficient was significant ( $p$ $<0.001$ ), indicating that it is an important variable in predicting if a student will 
be placed in the higher group (above P75) among all students from the courses for each of the courses.

\section{Declarations}

Conflict of interest On behalf of all authors, the corresponding author states that there is no conflict of interest.

\section{References}

ABMES [Brazilian Association of Higher Education Maintainers] (2019) Educação Superior no Brasil: panorama geral, Brasília: ABMES educainsights. Retrieved from https://abmes.org.br/arquivos/ pesquisas/contexto_brasil.pdf

Altbach, P., Reisberg, L. and Rumbley, L. (2009) Trends in Global Higher Education: Tracking an Academic Revolution, Paris: UNESCO. ED.2009/CONF.402/INF.6.

Altbach, P., Reisberg, L. and Wit, H. (2017) Responding to massification: Differentiation in postsecondary education worldwide, Rotterdam: Springer.

Alves, R. A. (2017) "Um Estudo de Transformações Educacionais e Sociais em Contextos Amazônicos sob a Égide da Universidade Aberta do Brasil: Breves e São Sebastião da Boa Vista - Um Mundo Não Tão a Parte.” PhD Thesis, University of São Paulo. Mimeo.

Bertolin, J. and Marcon, T. (2015) 'O (des) entendimento de qualidade na educação superior brasileiraDas quimeras do provão e do ENADE à realidade do capital cultural dos estudantes', Avaliação: Revista da Avaliação da Educação Superior 20(1): 105-122.

Bertolin, J., Amaral, A. and Almeida, L. (2019) 'Os Cursos de Graduação Podem Compensar a Falta de Capital Cultural e Background de Estudantes?', Educação e Pesquisa advance online publication January 17. https://doi.org/10.1590/s1678-4634201945185453.

Betts, J. and Morell, D. (1999) The Determinants of Undergraduate Grade Point Average: The Relative Importance of Family Background, High School Resources, and Peer Group Effects. The Journal of Human Resources 34(2): 268-293

Boliver, V. (2011) Expansion, differentiation, and the persistence of social class inequalities in British higher education. Higher Education 61(3): 229-242

Bolton, D., Smidt, E. and Li, R. (2019) 'Assessing the Quality of Distance Education at a University', in E. Smidt and R. Li (eds.) Ensuring Quality and Integrity in Online Learning Programmes, Hershey: IGI Global, pp. 149-177.

Bourdieu, P. (1966) 'L'école conservatrice. Les Inégalités Devant L'école El La Culture.' Revue Française De Sociologie 7: 325-347

Brighouse, H. (2009) Justice in Higher Education: an odd view. Paper presented at the Society of Applied Philosophy meeting at the Eastern American Philosophical Association; 29 December, New York, USA.

Bruinsma, M. (2003) 'Effectiveness of higher education: Factors that determine outcomes of university education', PhD dissertation, University of Groningen.

Bielschowsky, C. (2018) 'Qualidade na Educação Superior a Distância no Brasil: Onde Estamos, para Onde Vamos?', Rev. EAD em Foco advance online publication March 28. https://doi.org/10.18264/ eadf.v8i1.709.

Calderon, A. (2018) Massification of higher education revisited, Melbourne: RMIT University.

Cheng, Y.C. and Tam, W.M. (1997) Multi-models of quality in education. Quality Assurance in Education 5(1): 22-31

Coleman, J., Campbell, E.Q., Hobson, C.J., McPartland, J., Mood, A.M., Weinfeld, F.D. and Yrok. R.L. (1966) Equality of Educational Opportunity. Washington, DC: U.S. Government Printing Office. DHEW Report Number OE-38001.

Cross, D., Thomson, S and Sinclair, A. (2017) Research in Brazil. A report for CAPES, Philadelphia: Clarivate Analytics. 
Cyrulnik, B. (2020) 'A desigualdade social começa nos mil primeiros dias de vida', El País, 12 March, https://brasil.elpais.com/internacional/2020-02-12/boris-cyrulnik-a-desigualdade-social-comecanos-mil- primeiros-dias-de-vida.html, accessed 12 March 2020.

Denice, P. (2015) Does it pay to attend a for-profit college? Vertical and Horizontal Stratification in Higher Education. Social Science Research 52: 161-178

DOE [Department of Education Republic of South Africa] (2010) Education Statistics in South Africa 2008. Pretoria: Government Printing Works.

EC [European Commission], (2010) Efficiency and effectiveness of public expenditure on tertiary education in the EU, Brussels: Publications office of the European Union. European Economy Occasional Papers no, p. 70.

Figueiredo, M., Amaral, R. and Ropoli, E. (2017) Avaliação dos cursos de graduação: estudo comparativo entre cursos oferecidos nas modalidades a distância e presencial. Paper presented at the Congresso ABED, 2017; 20 September, Foz do Iguaçu, Brasil.

Gerber, T. and Cheung, S. (2008) Horizontal Stratification in Postsecondary Education: Forms, Explanations, and Implications. Annual Review of Sociology 34(1): 299-318

INEP [National Institute for Educational Studies and Research Anísio Teixeira] (2019) Microdados. INEP open data, https://www.gov.br/inep/pt-br/acesso-a-informacao/dados-abertos/microdados, accessed 26 May 2020.

Harvey, L. and Green, D. (1993) Defining quality. Assessment and Evaluation in Higher Education 18: 8-35

Herbaut, E. and Geven, K. (2019) What works to reduce inequalities in Higher Education? A systematic review of the (quasi-) experimental literature on outreach and financial aid, Washington, DC: World Bank Group. Policy Research Working Paper 8802.

Laurillard, D. (2013) Rethinking university teaching: A conversational framework for the effective use of learning technologies, Abingdon: Routledge.

Laurillard, D., and Kennedy, E. (2017). The potential of MOOCs for learning at scale in the Global South. CGHE Working Paper No. 31. London: Centre for Global Higher Education.

Marginson, S. (2004) 'Australian higher education: National and global markets', in P. Teixeira, B. Jongbloed, D. Dill and A. Amaral (eds.) Markets in Higher EducationDordrecht: Springer, pp. 207-240.

Marinoni, G., van't Land, H. and Jensen, T. (2020) The impact of Covid-19 on higher education around the world. IAU Global Survey Report. Paris: International Association of Universities.

McCowan, T. (2012) Is there a universal right to higher education? British Journal of Educational Studies 60(2): 111-128

McCowan, T. (2016) Three dimensions of equity of access to higher education. Compare 46(4): 645-665

McCowan, T. and Bertolin, J. (2020) Inequalities in Higher Education Access and Completion in Brazil, Geneva: UNRISD. Universities and Social Inequalities in the Global South - Working Paper 2020-3.

Morche, B. (2012) Inclusión y exclusión en el sistema educativo: la expansión de la educación superior en Brasil India y China. Revista Mad 27: 44-52

OECD [Organization for Economic Co-operation and Development] (2018) Rethinking Quality Assurance for Higher Education in Brazil. Available at https://www.oecd.org/brazil/rethinking-qualityassurance-for-higher-education-in-brazil-9789264309050-en.htm, accessed 2 may 2021.

Pinho, A. (2019) 'Em 1 ano, ensino a distância rouba 120 mil alunos de cursos presenciais', Jornal Folha de São Paulo, 14 October, https://www1.folha.uol.com.br/educacao/2019/10/em-1-ano-ensino-adistancia- rouba-120-mil-alunos-de-cursos-presenciais.shtml accessed 25 November 2019.

Salmi, J. (2020) Covid's Lessons for Global Higher Education, Indianapolis: Lumina Foundation

Schwartzman, S., Silva Filho, R. and Coelho, R. (2021) Por uma tipologia do ensino superior brasileiro: teste de conceito. Estudos Avançados 35(101): 153-186. https://doi.org/10.1590/s0103-4014.2021. 35101.011

Silió, E. (2019) 'La creación de un ministerio solo de Universidad solivianta a rectores, científicos y sindicatos', El País 31 December, https://elpais.com/sociedad/2019/12/31/actualidad/1577803523_ 293257.html accessed 24 March 2020.

Tam, M. (2001) Measuring Quality and Performance in Higher Education. Quality in Higher Education. 7(1): 47-54

Todos pela Educação (TPE) [All for education] (2019) Formação inicial de professores no Brasil, São Paulo: Todos Pela Educação.

Triventi, M. (2013) Stratification in higher education and its relationship with social inequality: A comparative study of 11 European countries. European Sociological Review 29(3): 489-502 
Trow, M. (1973) Problems in the transition from elite to mass higher education, Berkley: Carnegie Commission on Higher Education. Document Resume No. ED 091: 983

UNESCO [United Nations Educational, Scientific and Cultural Organization] (2020) Enrolment by Level of Education. UNESCO Institute for Statistics, http://data.uis.unesco.org/, accessed 24 January 2021.

WID [World Inequality Database] (2015) World Inequality Database. WID.WORLD, https://wid.world/, accessed 19 November 2019.

World Bank (2020) Gini Index. https://data.worldbank.org/indicator/SI.POV.GINI?most_recent_value_ desc $=$ true, accessed 24 January 2021 .

Ziguras, C. (2018) 'Will global online higher Education ever take off?', University World News 19 January, https://www.universityworldnews.com/post.php?story=20180116150633478 accessed 25 March 2020.

Publisher's Note Springer Nature remains neutral with regard to jurisdictional claims in published maps and institutional affiliations. 